\title{
Peristaltic infusion of red blood cells: analysis of hemolysis ratio, plasma hemoglobin and potassium levels
}

\author{
M Pedreira*, MA Peterlini, AM Avelar, DM Kusahara \\ From ESICM LIVES 2015 \\ Berlin, Germany. 3-7 October 2015
}

\section{Introduction}

It is unclear whether the use of linear peristaltic infusion pumps with different propulsion mechanisms can affect the quality of red blood cells (RBCs) transfusion. We hypothesized that the mechanism of liquid propulsion, infusion rate, complete or incomplete compression of the infusion sets segment and type of pumping segment composition materials are variables that can influence $\mathrm{RBC}$ infusion quality.

\section{Objectives}

To analyze the effects of two linear peristaltic infusion pumps on RBC hemolysis ratio, plasma hemoglobin and potassium levels, according to the use two different infusion rates.

\begin{abstract}
Methods
Experimental transfusions of RBC simulating nursing clinical practice were accomplished in three linear peristaltic infusion pumps with horizontal peristaltic finger mechanism (A) and three linear peristaltic infusion pumps with a vertical peristaltic mechanism that compress the administration tube halfway to closure (B). The infusion pumps were set at $100 \mathrm{ml} / \mathrm{h}$ and $300 \mathrm{ml} / \mathrm{h}$. The six pumps and the two infusion rates were randomly submitted to analysis. Plasma hemoglobin (g/dl), hemolysis ratio (\%) and potassium levels $(\mathrm{mmol} / \mathrm{L})$ were assessed in $\mathrm{RBC}$ before manipulation directly from the $\mathrm{RBC}$ bag ( $\mathrm{C} 1)$, after free flow through the macro drip intravenous infusion sets $(\mathrm{C} 2)$ and after infusion by the peristaltic mechanisms (E). Data were analyzed according to mean, standard deviation, and t test, significance level set as $\mathrm{p} \leq 0.05$.
\end{abstract}

\section{Results}

A significant effect of the pump mechanism was verified between infusion pumps $A$ and $B$ only in plasma hemoglobin $(\mathrm{A}=0.419 \pm 0.216 ; \mathrm{B}=0.251 \pm 0.205 ; \mathrm{p}=$ $0.021)$. A statically similar plasma potassium level $(\mathrm{A}=39.6 \pm 3.0 ; \mathrm{B}=40.3 \pm 2.3 ; \mathrm{p}=0.471)$ and hemolysis ratio $(\mathrm{A}=0.582 \pm 0.256 ; \mathrm{B}=0.392 \pm 0.404 ; \mathrm{p}=0.089)$ were obtained. Hemolysis between $\mathrm{C} 1$ to $\mathrm{C} 2$ and $\mathrm{E}$ presented variation in infusion pump A ranging from 0.503 $( \pm 0.740)$ in $C 1,0.417( \pm 0.610)$ in $C 2$ and to 1.131 $( \pm 1.180)$ in $\mathrm{E}$. According to the studied infusion rates, hemolysis was higher to infusion pump A at $100 \mathrm{ml} / \mathrm{h}$ $(\mathrm{p}<0.0001)$ and infusion pump B at $300 \mathrm{ml} / \mathrm{h}(\mathrm{p}=$ $0.004)$. The plasma hemoglobin level was higher in infusion pumps $\mathrm{A}$ at $100 \mathrm{ml} / \mathrm{h}(\mathrm{p}=0.009)$ and similar between pumps $(\mathrm{p}=0.576)$ at $300 \mathrm{ml} / \mathrm{h}$. The plasma potassium level variation according to infusion rates did not present significant variation $(\mathrm{p}>0.05)$.

\section{Conclusions}

Comparisons between pumps demonstrated a higher increment of plasma hemoglobin in infusion pump A. According to the studied rates, hemolysis ratio was higher in infusion pump A at $100 \mathrm{ml} / \mathrm{h}$ and in infusion pump B at $300 \mathrm{ml} / \mathrm{h}$; plasma hemoglobin was higher in infusion pump A at $100 \mathrm{ml} / \mathrm{h}$; plasma potassium levels had no significant variations. A hemolysis ratio higher than $0.8 \%$ was verified only in infusion pump A at $100 \mathrm{ml} / \mathrm{h}$.

\section{Grant Acknowledgment}

FAPESP-Sao Paulo Research Foundation n.12/25284-9.

Published: 1 October 2015 
doi:10.1186/2197-425X-3-S1-A921

Cite this article as: Pedreira et al.: Peristaltic infusion of red blood cells: analysis of hemolysis ratio, plasma hemoglobin and potassium levels. Intensive Care Medicine Experimental 2015 3(Suppl 1):A921.

\section{Submit your manuscript to a SpringerOpen ${ }^{\circ}$ journal and benefit from:}

- Convenient online submission

- Rigorous peer review

- Immediate publication on acceptance

- Open access: articles freely available online

- High visibility within the field

- Retaining the copyright to your article

Submit your next manuscript at $\gg$ springeropen.com 